\title{
Allograft for Myeloma: Examining Pieces of the Jigsaw Puzzle
}

\author{
Ehsan Malek ${ }^{1 *}$, Najla El-Jurdi', Nicolaus Kröger ${ }^{2}$ and Marcos de Lima \\ 'Stem Cell Transplant Program, University Hospitals Seidman Cancer Center, Case Comprehensive Cancer Center, \\ Case Western Reserve University, Cleveland, $\mathrm{OH}$, United States, ' 2 Department of Stem Cell Transplantation, University \\ Medical Center Hamburg-Eppendorf, Hamburg, Germany
}

Multiple myeloma (MM) cure remains elusive despite the availability of newer antimyeloma agents. Patients with high-risk disease often suffer from early relapse and short survival. Allogeneic hematopoietic cell transplantation (allo-HCT) is an "immune-based" therapy that has the potential to offer long-term remission in a subgroup of patients, at the expense of high rates of transplant-related morbidity and mortality. Donor lymphocyte infusion (DLI) upon disease relapse after allo-HCT is able to generate an anti-myeloma response suggestive of a graft-versus-myeloma effect. Allo-HCT provides a robust platform for additional immune-based therapy upon relapse including DLI and,

\section{OPEN ACCESS}

Edited by:

Alessandro Gozzetti,

University of Siena, Italy

Reviewed by:

Alessandro Isidori,

AORMN Hospital, Italy

Paul Armistead,

University of North Carolina at Chapel Hill, United States

*Correspondence: Ehsan Malek exm301@case.edu

Specialty section: This article was submitted to Hematology Oncology, a section of the journal Frontiers in Oncology

Received: 14 September 2017 Accepted: 13 November 2017 Published: 11 December 2017

Citation:

Malek E, El-Jurdi N, Kröger N and de Lima M (2017) Allograft for Myeloma: Examining Pieces of the Jigsaw Puzzle. Front. Oncol. 7:287. doi: 10.3389/fonc.2017.00287 maintenance with immunomodulatory drugs and immunosuppressive therapy. There have been conflicting findings from randomized prospective trials questioning the role of allo-HCT. However, to this date, allo-HCT remains the only potential curable treatment for $\mathrm{MM}$ and its therapeutic role needs to be better defined especially for patients with high-risk disease. This review examines different aspects of this treatment and summarizes ongoing attempts at improving its therapeutic index.

Keywords: allogeneic, hematopoietic stem cells, multiple myeloma, allograft, allograft for myeloma

\section{INTRODUCTION}

Multiple myeloma is a largely incurable disease that has benefited from the advent of novel agents over the last decade. Allogeneic hematopoietic cell transplantation (allo-HCT) remains the only potentially curative treatment; however, its use is controversial given its high morbidity and mortality. Alloreactive immune effector cells originating from a myeloma-free graft exert graftversus-myeloma (GVM) effects leading to long-term control of disease $(1,2)$. Evidence for this GVM effect is provided by reports of sustained molecular remissions achieved by donor lymphocyte infusion (DLI) after allo-HCT (3). Currently, high-dose melphalan followed by autologous hematopoietic cell transplantation (auto-HCT) remains the standard-of-care for suitable patients with MM, as demonstrated by the recent report of the IFM 2009 trial (4). Historically, there have been significant efforts to modulate different elements of allo-HSCT to improve outcomes while minimizing regimen-related toxicity and graft-versus-host disease (GVHD). In the following sections, we will discuss different components of allo-HCT in MM and how they may guide our optimal choice of therapy for MM. There include: patient selection, graft source, conditioning regimen, posttransplant maintenance therapy, and the role of DLI. This review examines these crucial steps of allo-HSCT separately in the context of emerging new data. 


\section{PATIENT SELECTION}

The risk-benefit ratio of allo-HCT in standard-risk MM is questionable. The BMT CTN 0102 trial randomized standard risk MM patients (defined by Beta- 2 microglobluin $<4 \mathrm{mg} / \mathrm{L}$, absence of chromosome 13 deletion, and no progression after initial chemotherapy) to tandem auto-HCT $(n=366)$ or autoHCT followed by matched related donor (MRD) allo-HCT $(n=156)(5)$. There was no difference in relapse rate or overall survival (OS) between the two arms with more treatmentrelated mortality (TRM) in patients who received auto-HCT followed by allo-HCT (4 versus $11 \%$, $p$-value $<0.0001$ ). Similarly, another large study, HOVON-50 trial, did not support the broad application of allo-HCT in MM (6). In this trial, the outcomes of 122 patients who had an HLA-identical sibling donor (donor group) and underwent allo-HCT after a planned auto-HCT were compared prospectively to 138 patients without a donor who underwent maintenance therapy or second auto-HCT after the first auto-HCT. PFS was significantly prolonged in patients who proceeded to allo-HCT compared to maintenance or second auto-HCT. However, after a median follow-up of 77 months complete remission (CR) rate as well as OS was similar between the two groups with higher 6-year TRM in the allo-HCT group (16 versus $3 \%$, $p$-value $<0.001$ ). In the European Group for Blood and Marrow Transplantation Non-Myeloablative Allogeneic Stem Cell Transplantation in multiple myeloma (EBMT-NMAM2000 study), patients with an HLA-identical sibling $(n=108)$ receiving auto-HCT/RIC allo-HCT were compared to 249 patients that received tandem auto-HCT. This study demonstrated improved PFS and OS in the auto-HCT/RICallo-HCT arm (OS 49 versus $36 \%$ at 96 months, respectively, $p=0.030$ ), at the expense of higher TRM (13 and $3 \%$, respectively). Interestingly, the RIC/allo-HCT approach seemed to overcome the poor prognostic implication of del(13) (7). However, none of the patients received any novel agents during induction or maintenance and FISH data was not available for all patients for risk stratification.

Crucial to interpreting these studies is the fact that novel agents and auto-HCT have enhanced OS of MM patients from a median of 3-5 years in the 1990 s to over 10 years currently (8). Therefore, it is harder to justify allo-HCT for standard risk disease in the era of novel agents $(9,10)$.

\section{Can Allograft Negate High-Risk Factors?}

Despite the development of new anti-myeloma therapeutic agents, outcomes for high-risk MM remain dismal. High-risk disease is usually defined by the presence of chromosomal abnormalities including $\mathrm{t}(4,14), \mathrm{t}(14,16), \mathrm{t}(14,20), 1 \mathrm{q}$ amplification or 1p deletion, $17 \mathrm{p}$ deletion and chromosome 13 deletion (i.e., detected on conventional cytogenetic only). This group accounts for $20 \%$ of newly diagnosed cases and is associated with early relapse and death (11). A small fraction of MM patients clinically behave aggressively despite lacking "high-risk" chromosomal abnormalities. This includes patients who relapse in a short period of time after auto-HCT ( $<12$ months) $(12,13)$ or patients diagnosed with plasma cell leukemia (14). Allo-HCT may have an important role to improve outcomes in such patients.
Schilling et al. reported on 101 patients treated with alloHCT utilizing fludarabine and melphalan conditioning regimen (15). Presence of $t(4,14)$ did not influence outcomes, suggesting that allo-HCT may overcome the influence of this poor prognosis marker. In a multivariate analysis, however, del(13) (HR: $2: 34, p=0.03)$ and $\operatorname{del}(17)$ (HR: $2.24, p=0.04)$ were predictors of relapse. In a report of $143 \mathrm{MM}$ patients who underwent allo-HCT with mostly RIC regimens (77\%), the 3-year PFS and OS did not differ for patients with or without del (13), $\mathrm{t}(4,14)$, del(17), or $\mathrm{t}(11,14)(16)$. In the EBMT-NMAM2000 trial, patients with del(13) allocated to the auto-HCT/allo-HCT group had a survival benefit when compared to the tandem auto-HCT group with PFS and OS of 21 and $47 \%$ versus $5 \%$ $(p=0.026)$ and $31 \%(p=0.154)$, respectively $(7)$. Nishihori et al. reported the outcome of $22 \mathrm{MM}$ patients in very good partial response or CR who underwent HLA-identical sibling allo-HCT as consolidation therapy (17). They showed a 2 -year PFS of $74.8 \%$, which compared favorably to $52 \%$ PFS in historical controls treated with auto-HCT. In another study by Kröger et al., the 5-year PFS among 16 high-risk MM patients, defined by del $(17 \mathrm{p})$ and/or $\mathrm{t}(4,14)$, and 57 non-high risk patients who underwent auto-allo tandem was not significantly different (24 versus $30 \%, p=0.7$ ) (18). In another report of auto-allo among MM patients with chromosome 13 deletion, allo-HCT could overcome del (17) poor prognostic factor [median PFS: 6 months with auto-auto versus not reached with auto/allo SCT $(p=0.0002)](19)$.

Overall, it seems that allo-HCT may negate some features of high-risk disease. However, there is an unmet need for trials to define the best use of allo-HCT incorporating novel agents for these patients. The ongoing U.S. BMT CNT 1302 trial tests the application of allo-HCT for this population.

\section{GRAFT SELECTION}

\section{Bone Marrow versus Peripheral Blood (PB) Hematopoietic Stem Cells}

Mobilized PB hematopoietic cells have been widely adopted as the graft source of choice in allo-HCT for MM since 1994, despite the lack of prospective studies comparing stem cell sources in this setting. The largest retrospective study evaluating graft source was performed by the EBMT registry (20). Transplants performed between 1983 and 1993 ( $n=334$ all with BM source) were compared to transplants done between 1994 and 1998 (BM, $n=223$ and $\mathrm{PB}, n=133$ ). Median OS was 10 and 50 months, respectively, for patients transplanted with $\mathrm{BM}$ in the earlier and later time periods reflecting an overall reduction in TRM, possibly owing to better supportive care and infection control. The use of PB as the graft source resulted in earlier engraftment without significant OS benefit (20).

\section{Donor Selection}

A matched-related sibling donor is traditionally considered the first choice for patients undergoing allo-HCT. However, a significant proportion of patients will not have such a donor. Kröger et al. conducted a phase II multicenter EBMT trial, where 
49 patients with relapsed MM after an autologous HCT received allo-HCT from an unrelated donor (21). One-year TRM rate was 10 versus $53 \%$ in patients receiving fully HLA matched versus mismatched grafts. Umbilical cord blood (CB) has also been investigated as an alternative donor source for those without a matched related or unrelated donor. Less stringent matching criteria and lower rates of acute and chronic GVHD are often cited as advantages of using CB. Major disadvantages include delayed neutrophil and platelet engraftment with higher rates of graft failure. Kawamura et al. retrospectively analyzed the Japanese registry data to assess transplant outcomes in 86 patients who underwent a CBT with RIC (RIC-CBT) (22). Six-year PFS and OS were 13 and $15.2 \%$, respectively. Development of chronic GVHD, prior transplantation, and planned tandem autologous HCT followed by RIC-CBT were associated with better OS. The cumulative incidence of 2-year non-relapse mortality (NRM) was $39 \%$, which is higher than recent studies using RIC and allo-HCT for myeloma. Interestingly, NRM was only $6.2 \%$ for patients who underwent planned autologous HCT followed by RIC-CBT (22). In another retrospective registry-based study, 95 patients receiving either a single or double CBT were analyzed (23). The 3-year PFS and OS were 24 and $40 \%$, respectively. On subgroup analysis, patient with high-risk cytogenetics had a higher relapse rate, and worse PFS and OS. There are few reports using haploidentical donors; the largest case series included 30 heavy-treated MM patients who underwent haplo-HCT with post-HCT cyclophosphamide as GVHD prophylaxis. The rate of aGVHD, cGVHD, NRM, and relapse rate at 18 months were $29,7,10$, and $42 \%$, respectively. Median neutrophil and platelet engraftments at day +30 were $87 \%$ [ $95 \%$ confidence interval (CI), 66-95\%] and 60\% [95\% CI, 40-75\%], respectively. The 18 -month PFS and OS were 33 and 63\%, respectively. No differences were observed between $\mathrm{PB}$ and bone marrow graft in terms of engraftment, GVHD, or PD incidence (24). In another study, 10 patients with relapsed MM who received haploidentical allo-HCT with posttransplant cyclophosphamide; six patients received BM and four patients received PB graft (25). Nine patients engrafted with full donor chimerism; there were no deaths due to acute or chronic GVHD and the 2-year OS was $46 \%$. Given this limited experiences, alternative donor HCT for MM should be investigated in prospective studies before firm recommendations can be made.

\section{Graft Manipulation}

CD34+ selected grafts reduce the incidence of GVHD, potentially compromising the GVM effect with higher posttransplant relapse rates. T-cell depletion in an effective GVHD prophylaxis approach, associated with impaired immune reconstitution and higher incidence of graft failure and posttransplant lymphoproliferative disorders (26). Since RIC allo-HCT relies mainly on alloimmunity and the GVM effect rather than the cytotoxic effect of the conditioning regimen, in vivo $\mathrm{T}$-cell depletion using alemtuzumab might not be the optimal approach. Antithymocyte globulin (ATG) may render a direct anti-myeloma effect; therefore, its use for T-cell depletion should be investigated further $(27,28)$. Soiffer et al. reported a retrospective analysis of patients who underwent allo-HCT for hematological malignancies and showed a lower GVHD incidence with T-cell depleted grafts, but with worse PFS (29). In order to retain the lower TRM associated with RIC regimens and potentiate the GVM effect, some investigators used CD34-selected grafts followed by prophylactic DLI. Smith et al. treated 44 patients with relapsed, high-risk MM with HLA-matched donors with low-dose prophylactic DLI starting 4-6 months posttransplant (30). The reported 2 -year PFS and OS were 31 and 54\%, respectively. Acute GVHD incidence was $2 \%$ and the 1 -year TRM rate was $18 \%$. The use of DLI and other posttransplant adoptive immunotherapies to potentiate the GVM effect is discussed below. However, T cell depletion remains controversial and institutional or investigator experience often dictates the approach to graft manipulation.

Shah et al. recently demonstrated the potential of using third-party, ex vivo expanded, CB-derived natural killer (NK) cells prior to auto-HCT, potentially providing an anti MM effect in this setting. Importantly, donor NK cells, with an activated phenotype (NKG2D+/NKp30+), were detected in vivo in 6 out of 12 (50\%) MM patients who were enrolled on the phase I therapy of combined auto-HCT and CB-derived NK cell therapy $(31,32)$.

The NK antitumor activity is mediated mostly through several receptor families including killer cell immunoglobulin-like receptors (KIRs). KIR loci are located on chromosome 19 and segregated independently from HLA genes; therefore, they are not matched between recipients and donors frequently. KIR mismatch most likely leads to higher NK alloreactivity and several reports showed a significant benefit of KIR mismatch in outcome after allogeneic stem cell transplantation $(33,34)$.

\section{CONDITIONING REGIMEN}

Myeloablative conditioning regimens are generally associated with higher TRM rates mostly due to infection, GVHD, and regimen-related toxicities (35). The most common conditioning regimens incorporate Cyclophosphamide (Cy) and total body irradiation (TBI); Busulfan (Bu) and $\mathrm{Cy}$; Bu/Cy/TBI and Melphalan (Mel) with TBI (Table 1). In the S9321 clinical trial, patients in the allo-HCT arm received the myeloablative conditioning regimen of Melphalan plus TBI. TRM was 53\% leading to early closure of the allo-HCT arm (36). In another trial, the Haemato-Oncology Foundation for Adults in the Netherlands (HOVON-24) study, TRM was 30\% with dismal PFS and OS for patients who underwent partially T-cell-depleted myeloablative allo-HCT with Cy/TBI conditioning regimen (37). Bensinger et al. compared the outcome of 144 patients who underwent allo-HCT utilizing high-dose myeloablative regimens with 134 patient who received RIC and non-myeloablative (NMA) regimens. Intensity of the conditioning regimen was predictive of higher acute GVHD and TRM rates, earlier relapse, and inferior OS (38). Prior auto-HCT was the main predictor of high TRM after allo-HCT across a variety of conditioning regimen intensities. Other groups reported a similar correlation between prior auto-HCT as well as time between auto-HCT and allo-HCT as another poor prognostic factor and predictor of higher TRM (39). These results suggest that prior exposure to melphalan adds to the toxicity of allo-HCT. 
Higher TRM rates associated with myeloablative regimens lead to alternatively exploring NMA and RIC regimens. The CIBMTR database shows a significant shift from intensive regimens from the 1990s to the early 2000s (42). Most of these regimens contain Mel $100-140 \mathrm{mg} / \mathrm{m}^{2}$ plus other agents (43). This approach leads to expansion of allo-HCT eligibility criteria by including older patients. Interestingly, higher relapse rates often negated the lower TRM benefit of RIC leading to similar OS.

The strategy of cytoreduction with auto-HCT before RIC allo-HCT has been investigated extensively. Several large prospective randomized trials compared auto-HCT followed by RICallo-HCT to tandem auto-HCT as consolidation therapy

TABLE 1 | Outcomes of allogeneic stem cell transplant with myeloablative conditioning regimens in prospective studies.

\begin{tabular}{|c|c|c|c|c|}
\hline $\begin{array}{l}\text { Conditioning } \\
\text { regimen }\end{array}$ & $\begin{array}{c}\text { Number of } \\
\text { patients }\end{array}$ & TRM (\%) & $\begin{array}{l}\text { PFS/OS } \\
\text { (months) }\end{array}$ & Reference \\
\hline $\begin{array}{l}\text { CyTBI } \\
\text { MelTBI } \\
\text { BuCy }\end{array}$ & $334^{a}$ & 46 & NA/35 & $(40)$ \\
\hline $\begin{array}{l}\text { CyTBI } \\
\text { MelTBI } \\
\text { BuCy }\end{array}$ & $356^{b}$ & 30 & NA/55 & (20) \\
\hline $\begin{array}{l}\text { CyTBI } \\
\text { BuCy }\end{array}$ & 66 & 24 & $26 / 39$ & $(41)$ \\
\hline $\begin{array}{l}\text { BuCyTBI } \\
\text { BuCy }\end{array}$ & 80 & 44 & $62 / 39$ & (35) \\
\hline $\begin{array}{l}\text { Cy/TBI } \\
\text { MelTBI }\end{array}$ & $\begin{array}{l}53 \\
36\end{array}$ & $\begin{array}{l}34 \\
53\end{array}$ & $\begin{array}{c}18 / 25 \\
N^{c}\end{array}$ & $\begin{array}{l}(37) \\
(36)\end{array}$ \\
\hline
\end{tabular}

a1983-1993.

b1994-1998.

'Trial was stopped due to excessive TRM.

${ }^{d}$ At 3 years.

TRM, transplant related mortality; PFS, progression-free survival; OS, overall survival;

Cy, cyclophosphamide; TBI, total body irradiation; Mel, melphalan; Bu, Busulfan.
(Table 2). However, there is a high degree of heterogeneity among these trials, including use of different conditioning regimens and use of novel agents. Overall, it seems that patients who underwent allo-HCT after auto-HCT are at a higher risk of TRM. A meta-analysis of six studies compared 1,192 patients who underwent tandem auto-HCT to 630 patients who received auto-HCT followed by RIC allo-HCT (44). Recipients of autoHCT and RIC allo-HCT had higher TRM and CR rates, without PFS or OS advantage.

\section{GVHD Prophylaxis}

Several investigators have attempted to modify the standardof-care calcineurin inhibitor-based GVHD prophylaxis regimens. There are preclinical data supporting the use of bortezomib for GVHD prophylaxis. Bortezomib protects against acute GVHD without impairing engraftment or GVT response in murine models of HLA-mismatched allo-HCT $(48,49)$. This effect is likely due to a suppressive effect of proteasome inhibition on NF-kB, an important modulator of alloreactive T-cell-mediated GVHD $(50,51)$, in addition to possible modulation effect on antigen-presenting cells (52). Proteasome inhibitors deplete proliferating alloreactive T lymphocytes, suppress TH1 cells, and affect antigen-presenting capacity $(51,52)$. A phase I/II trial was conducted to investigate the use of bortezomib-based GVHD prophylaxis after HLA-mismatched unrelated donor RIC HCT (53). Bortezomib was given on days $+1,+4$, and +7 in addition to calcineurin inhibitor and methotrexate with minimal systemic toxicity and GVHD rates similar to HLA-matched allo-HSCT. Koreth et al. investigated the use of bortezomib in addition to tacrolimus and low-dose methotrexate as GVHD prophylaxis in patients with hematologic malignancies that underwent alloHCT with 1 or 2 HLA-mismatched donor (54). The drug was used in three dose levels of $1,1.3$, and $1.5 \mathrm{mg} / \mathrm{m}^{2} \mathrm{IV}$ on days $+1,+4$, and +7 posttransplant (fludarabine and busulfan conditioning regimen). The maximum tolerated dose was $1.3 \mathrm{mg} / \mathrm{m}^{2}$. Cumulative incidence of grade II-IV acute GVHD was $22 \%$ with

TABLE 2 | Comparison of clinical outcomes of tandem auto-HCT and auto-HCT followed by RIC allo-HCT in prospective randomized trials.

\begin{tabular}{|c|c|c|c|c|c|c|c|c|}
\hline Study & Patients & Graft & Conditioning regimen & $\begin{array}{l}\text { GVHD } \\
\text { prophylaxis }\end{array}$ & TRM (\%) & CR (\%) & PFS (months) & OS (months) \\
\hline BMT CTN 0102 (5) & Standard risk (84\%) & MRD & TBI 2 GY & $\mathrm{CSA}+\mathrm{MMF}$ & $4 / 11^{a}$ & $45 / 58$ & $46 / 53$ & $80 / 77$ \\
\hline EBMT/NMAM 2000 (7) & Stable disease & MRD & TBI 2 GY/fludarabine ${ }^{b}$ & $\mathrm{CSA}+\mathrm{MMF}$ & $3 / 13$ & $41 / 50^{\circ}$ & $12 / 22^{d}$ & $36 / 49^{d}$ \\
\hline HOVON-50/54 (6) & All patients & MRD & TBI 2 GY & $\mathrm{CSA}+\mathrm{MMF}$ & $3 / 16$ & $37 / 43$ & $22 / 28^{e}$ & $55 / 55^{e}$ \\
\hline PETHEMA/GEM2000 (45) & All patients & MRD & Fludarabine/melphalan & $\mathrm{CSA}+\mathrm{MTX}$ & $5 / 16$ & $11 / 40$ & $31 /-^{f}$ & $58 /-^{f}$ \\
\hline IFM99-03/99-04 (46) & High-risk disease ${ }^{g}$ & MRD & Busulfan/fludarabine/ATG & $\mathrm{CSA}+\mathrm{MTX}$ & $5 / 10$ & & $35 / 31$ & $42 / 35$ \\
\hline Bruno et al. (47) & All patients & MRD & TBI 2 Gy & $\mathrm{CSA}+\mathrm{MMF}$ & $2 / 10^{h}$ & $26 / 55$ & $29 / 35$ & $54 / 80$ \\
\hline
\end{tabular}

Gray cells illustrated statistical significance.

${ }^{a}$ At 3 years.

b30 $\mathrm{mg} / \mathrm{m}^{2} \times 3$ days.

${ }^{\circ}$ At $60 \mathrm{~m}$.

${ }^{d}$ At 96 months.

${ }^{e}$ At 2 years.

${ }^{f}$ Not reached.

${ }^{9}$ Beta-2 micro $>3$ and 13 del at diagnosis with FISH.

${ }^{h}$ At 2 years.

GVHD, graft versus host disease; TRM, transplant related mortality; CR, complete response; PFS, progression-free survival; OS, overall survival; MRD, matched-related donor;

TBI, total body irradiation in Gray (GY); CSA, cyclosporine A; MMF, mycophenolate mofetil; MTX, methotrexate; ATG, antithymocyte globulin. 
1-year chronic GVHD incidence of 29\% while 2-year TRM rate was $11 \%$.

\section{MAINTENANCE}

Multiple studies showed the benefit of maintenance therapy with lenalidomide or bortezomib after auto-HCT for MM patients $(55,56)$. In contrast, there are scant data available on maintenance therapy post allo-HCT. Lenalidomide enhances anti-myeloma NK and NK/T-cell response and prolongs PFS and OS when used as maintenance therapy after auto-HCT (55, 57). Lenalidomide augments NK cell-derived antimyeloma activity while delaying recovery of regulatory $\mathrm{T}$ cells posttransplant (58). However, the possible immunostimulatory effect of this drug may lead to rapid onset and higher rates of acute GVHD (59), therefore, complicating its clinical use post allo-HCT. Dosing and timing seems to be crucial for lemalidomide maintenance post allo-HCT affecting NK and $\mathrm{T}$ cell activation (58). There is preclinical and clinical studies evidence suggesting that proteasome inhibitors can be safely used post allo-HCT. Moreover, these agents may suppress GVHD while preserving the GVM effect, and this hypothesis is under investigation in the U.S. BMT CTN 1302 trial utilizing the third generation proteasome inhibitor ixazomib as maintenance.

Bortezomib use after allo-HCT may add an anti-myeloma effect (60) without exacerbating GVHD. Kroger et al. administered maintenance bortezomib (Median: 7 months) for 18 MM patients with stable disease after RICallo-HCT (54). The drug was well tolerated with Grade III/IV neuropathy in three patients receiving cyclosporine, while three patients experienced mild aggravation of existing skin GVHD. In another study, 37 MM patients with residual or progressive disease after allo-HCT received bortezomib. Response rate was 73\% with two patients experiencing worsening GVHD.

\section{DONOR LYMPHOCYTE INFUSION}

As discussed previously, most allo-HCT for MM now use RIC regimens at the expense of higher relapse rates. RIC use is especially important in heavily pretreated and/or elderly patients who are not candidates for more intensive conditioning regimens. However, MM is considered to be of only intermediate susceptibility to the graft versus tumor effect. Several strategies have been explored to improve remission rates and decrease relapse risk.

Donor lymphocyte infusion given post allo-HCT is believed to augment the GVM effect. In 1996, Tricot et al. (61) reported CR with a single dose of CD3+ cells in a MM patient who had progressed after allo-HCT. This report was the first "proof of principle" for utilizing DLIs to induce a GVM effect. Although DLIs are mostly given in the context of refractory or progressive disease posttransplant (salvage DLI), this modality of adoptive immunotherapy has also been utilized preemptively posttransplantation (prophylactic DLI) (30, 62-70). Prophylactic DLI given at specific time points or in escalated incremental doses during $\mathrm{T}$-cell reconstitution are believed to enhance donor-derived T-cell reconstitution and to maximize GVM (70) (Tables 3 and 4).

Response rates as high as $52 \%$ have been reported $(72,73)$. However, in many studies, patients received additional therapies including chemotherapy before DLI to decrease "tumor burden" and improve chances of response. In other reports, DLIs have been combined with either immunomodulatory drugs or proteasome inhibitors.

Graft-versus-host disease is a significant risk associated with DLI that should be taken into consideration before selecting candidates for this treatment modality. The risk of both acute and chronic GVHD is reported to be as high as $60 \%$ in some studies. Development of GVHD has been associated with higher response rates but, this has not been consistent across different reports (73). In addition, neither the T-cell dose

TABLE 3 | Summary of studies utilizing donor lymphocyte infusion as a salvage strategy.

\begin{tabular}{|c|c|c|c|c|c|c|c|}
\hline Reference & $\begin{array}{l}\text { Number of } \\
\text { patients }\end{array}$ & Graft source & $\begin{array}{c}\text { T-cell dose } \times \\
10^{6} \text { cells } / \mathrm{kg} \text { (range) }\end{array}$ & $\begin{array}{l}\text { Response } \\
\text { rate (\%) }\end{array}$ & $\begin{array}{l}\text { GVHD (acute/ } \\
\text { chronic) }\end{array}$ & Survival outcomes & Additional treatment \\
\hline Lokhorst et al. (71) & 13 & MRD & $1-330$ & 62 & $9 / 7$ & 54\% 1-year OS & \\
\hline Salama et al. (72) & 25 & MRD/MUD & $2-224$ & 36 & $13 / 11$ & 48\% 1-year OS & $\begin{array}{l}\text { Interferon alpha, before } \\
\text { or after DLI }\end{array}$ \\
\hline Lokhorst et al. (3) & 27 & MRD & $1-500$ & 52 & $15 / 7$ & $\begin{array}{l}\text { Median OS: } \\
18 \text { months }\end{array}$ & $\begin{array}{l}\text { 13/27 re-induction chemotherapy } \\
\text { before DLI with: VAD, melphalan, } \\
\text { or dexamethasone }\end{array}$ \\
\hline Lokhorst et al. (73) & 54 & $\mathrm{MRD}$ & $1-500$ & 52 & $31 / 25$ & $\begin{array}{l}\text { PFS: } 19 \text { months } \\
\text { OS: } 23 \text { months }\end{array}$ & $\begin{array}{l}\text { 40/54 re-induction chemotherapy } \\
\text { before DLI with: VAD, melphalan, } \\
\text { or dexamethasone }\end{array}$ \\
\hline El-Cheikh et al. (64) & 9 & 5MRD/4MUD & $10-100$ & 75 & $1 / 0$ & $\begin{array}{l}50 \% \text { 2-year PFS } \\
69 \% \text { 2-year OS }\end{array}$ & Lenalidomide followed by DLI \\
\hline Montefusco et al. (74) & 19 & $16 \mathrm{MRD} / 3 \mathrm{MUD}$ & $0.5-100 \times 10^{6}$ & 68 & $2 / 5$ & $\begin{array}{l}\text { 31\% 3-year PFS } \\
73 \% \text { 3-year OS }\end{array}$ & $\begin{array}{l}\text { Bortezomib/dexamethasone } \\
\text { followed by DLI }\end{array}$ \\
\hline
\end{tabular}

GVHD, graft versus host disease; MRD, matched related donor; MUD, matched unrelated donor; PFS, progression-free survival; OS, overall survival;

$D L I$, donor lymphocyte infusion; $V A D$, vincristine, adriamycin, dexamethasone. 
TABLE 4 | Summary of studies utilizing prophylactic/pre-emptive DLI post allo-HCT.

\begin{tabular}{|c|c|c|c|c|c|c|c|}
\hline Reference & $\begin{array}{c}\text { Number of } \\
\text { patients }\end{array}$ & Graft source & $\begin{array}{l}\text { T-cell dose } \\
\times 10^{6} \text { (range) }\end{array}$ & $\begin{array}{c}\text { Response } \\
\text { rate }(\%)\end{array}$ & $\begin{array}{c}\text { GVHD (acute/ } \\
\text { chronic) }\end{array}$ & Survival outcomes & Additional treatment \\
\hline Alyea et al. (62) & 14 & MRD & 10-30 & 86 & 7 total $/ 5$ chronic & $65 \%$ 2-year PFS & Interferon alpha \\
\hline Badros et al. (63) & 14 & MRD & $120-220$ & 86 & $10 / 7$ & $69 \%$ 1-year OS & $\begin{array}{l}\text { Chemotherapy (DCEP) given post } \\
\text { allogeneic transplant fir large tumor } \\
\text { burden } \\
\text { Interferon alpha }\end{array}$ \\
\hline Peggs et al. (66) & 20 & 12 MRD/8 MUD & $1-100$ & 50 & $3 / 2$ & $\begin{array}{l}\text { 30\% 2-year PFS } \\
71 \% \text { 2-year OS }\end{array}$ & \\
\hline Peggs et al. (67) & 19 & MRD/MUD & $1-100$ & 63 & 9 total & NA & \\
\hline Kröger et al. (65) & 32 & $11 \mathrm{MRD} / 21 \mathrm{MUD}$ & $0.5-200$ & 78 & $13 / 15$ & 54\% 5-year PFS & $\begin{array}{l}\text { Thalidomide, Bortezomib, or } \\
\text { Lenalidomide added if no complete } \\
\text { remission achieved with DLI }\end{array}$ \\
\hline Smith et al. (30) & 44 & MRD & $0.5-1$ & NA & $1 / 0$ & $\begin{array}{l}\text { 31\% 2-year PFS } \\
54 \% \text { 2-year OS }\end{array}$ & \\
\hline
\end{tabular}

GVHD, graft versus host disease; response rate, complete or partial response; MRD, matched related donor; MUD, matched unrelated donor; PFS, progression-free survival; OS, overall survival; DCEP, dexamethasone; cyclophosphamide, etoposide, cisplatin; DLI, donor lymphocyte infusion.

TABLE 5 | Clinical trials using chimeric antigen receptor (CAR) modified T cells in multiple myeloma. ${ }^{a}$

\begin{tabular}{|c|c|c|c|c|}
\hline NCT\# & Study center & Phase & CAR construct & T cell origin \\
\hline NCT03070327 & Memorial Sloan Kettering Cancer Center, USA & 1 & EGFRt/B cell maturation antigen (BCMA)-41BBz & Auto/donor \\
\hline NCT02954445 & Southwest Hospital, China & $1 / I I$ & & Auto \\
\hline NCT01886976 & Chinese PLA General Hospital, China & $1 / \|$ & & Auto/donor \\
\hline NCT02203825 & Dana-Farber Cancer Institute, USA & । & Anti-BCMA-CAR-transduced T cells & Auto \\
\hline NCT02215967 & National Cancer Institute, USA & 1 & CART- 138 cells & Auto \\
\hline NCT02529813 & M.D. Anderson Cancer Center, USA & 1 & D19 + CAR T Cells & Auto \\
\hline NCT00881920 & Baylor College of Medicine, USA & 1 & Kappa CD28 T cells & Auto \\
\hline
\end{tabular}

ahttps://Clinicaltrials.gov accessed on 8/1/2017.

Key words: myeloma + CAR T.

nor converting patients from partial to full donor chimerism has been consistently associated with higher anti-myeloma response.

A study of frequent chimerism monitoring in 155 patients who underwent allo-HCT for MM showed that two-thirds of relapsing patients had full donor chimerism. Interestingly, one-third of patients had extramedullary disease despite donor hematopoietic reconstitution (75).

Donor-derived cytotoxic T-lymphocytes directed against myeloma-associated antigens such as Wilms tumor 1 (WT1) or other cancer testis antigens $(76,77)$ may enable a GVM effect without GVHD. Tyler et al. (77) reported a correlation between disease outcomes and WT1 expression by plasma cells in the bone marrow. Development of WT1 cytotoxic T-lymphocytes post allogeneic T-cell depleted transplant and DLI was associated with a GVM effect in the absence of GVHD.

\section{Chimeric Antigen Receptor (CAR) T Cells}

Allogeneic T cells are, as discussed above, frequently associated with off target effects such as GVHD and cytopenias. T cells genetically engineered with CARs expressing receptors to redirected specificity toward tumor cell antigens may generate a very specific GVM response, independent of HLA restriction $(78,79)$. CAR T cells targeting CD19 showed promising results in recent trials of CD19+ B cell malignancies (80-82) including a few MM cases (83). More recently, advances are being made using CAR T cells against myeloma-specific antigens such as $B$ cell maturation antigen (BCMA), CD138, NY-ESO-1, and kappa-light chain in addition to CD19. Although only a limited number of MM patients have been enrolled on CAR T cell trials, preliminary results are highly encouraging (Table 5). More recently, 33 out of 35 (94\%) MM patients with relapsed/refractory disease who enrolled on a phase I trial of CAR T cell BCMA treatment experienced clinical remission within first 2 months of therapy (84).

In addition, CAR T cells carry the hope of avoiding allo-HCT altogether. As CAR T cell technology advances, its potential use as a mean to armor "healthy" T cells is emerging as an important consideration. A detailed review of CAR T cells is beyond the scope of this article (85-87).

\section{CONCLUSION}

Allo-HCT highlights the potential of immune-based cell therapies for MM treatment. Improving risk models incorporating more sensitive minimal residual disease may lead to better patient selection and optimal structuring of different elements of the allo-HCT process in the future. In the U.S., the Centers for Medicare and Medicaid Services is considering MM as an indication for allo-HCT in the setting of an appropriate 
clinical trial applicable to the Medicare age population. The transplant community will be charged with better defining indications and limitations of this approach. Allo-HCT for MM should continue to be offered within a clinical trial designed to improve and understand the role of this therapeutic modality.

\section{REFERENCES}

1. Lokhorst H, Einsele H, Vesole D, Bruno B, San Miguel J, PérezSimon JA, et al. International Myeloma Working Group consensus statement regarding the current status of allogeneic stem-cell transplantation for multiple myeloma. J Clin Oncol (2010) 28(29):4521-30. doi:10.1200/ JCO.2010.29.7929

2. Libura J, Hoffmann T, Passweg J, Gregor M, Favre G, Tichelli A, et al. Graft-versus-myeloma after withdrawal of immunosuppression following allogeneic peripheral stem cell transplantation. Bone Marrow Transplant (1999) 24(8):925-7. doi:10.1038/sj.bmt.1701980

3. Lokhorst HM, Schattenberg A, Cornelissen JJ, van Oers MH, Fibbe W, Russell I, et al. Donor lymphocyte infusions for relapsed multiple myeloma after allogeneic stem-cell transplantation: predictive factors for response and long-term outcome. J Clin Oncol (2000) 18(16):3031-7. doi:10.1200/ JCO.2000.18.16.3031

4. Attal M, Lauwers-Cances V, Hulin C, Leleu X, Caillot D, Escoffre M, et al. Lenalidomide, bortezomib, and dexamethasone with transplantation for myeloma. NEngl J Med(2017) 376(14):1311-20. doi:10.1056/NEJMoa1611750

5. Krishnan A, Pasquini MC, Logan B, Stadtmauer EA, Vesole DH, Alyea E III, et al. Autologous haemopoietic stem-cell transplantation followed by allogeneic or autologous haemopoietic stem-cell transplantation in patients with multiple myeloma (BMT CTN 0102): a phase 3 biological assignment trial. Lancet Oncol (2011) 12(13):1195-203. doi:10.1016/S1470-2045(11) 70243-1

6. Lokhorst HM, van der Holt B, Cornelissen JJ, Kersten MJ, van Oers M, Raymakers R, et al. Donor versus no-donor comparison of newly diagnosed myeloma patients included in the HOVON-50 multiple myeloma study. Blood (2012) 119(26):6219-25. doi:10.1182/blood-2011-11-393801

7. Gahrton G, Iacobelli S, Björkstrand B, Hegenbart U, Gruber A, Greinix H, et al. Autologous/reduced-intensity allogeneic stem cell transplantation vs autologous transplantation in multiple myeloma: long-term results of the EBMT-NMAM2000 study. Blood (2013) 121(25):5055-63. doi:10.1182/ blood-2012-11-469452

8. Anderson KC. Progress and paradigms in multiple myeloma. Clin Cancer Res (2016) 22(22):5419-27. doi:10.1158/1078-0432.CCR-16-0625

9. Moreau P. Death of frontline allo-SCT in myeloma. Blood (2012) 119(26): 6178-9. doi:10.1182/blood-2012-04-420802

10. Stewart AK. Reduced-intensity allogeneic transplantation for myeloma: reality bites. Blood (2009) 113(14):3135-6. doi:10.1182/blood-2008-12173526

11. Avet-Loiseau H. Ultra high-risk myeloma. Hematology Am Soc Hematol Educ Program (2010) 2010(1):489-93. doi:10.1182/asheducation-2010.1.489

12. Jimenez-Zepeda VH, Reece DE, Trudel S, Chen C, Tiedemann R, Kukreti V. Early relapse after single auto-SCT for multiple myeloma is a major predictor of survival in the era of novel agents. Bone Marrow Transplant (2015) 50(2):204-8. doi:10.1038/bmt.2014.237

13. Majithia N, Rajkumar SV, Lacy MQ, Buadi FK, Dispenzieri A, Gertz MA, et al. Early relapse following initial therapy for multiple myeloma predicts poor outcomes in the era of novel agents. Leukemia (2016) 30(11):2208-13. doi:10.1038/leu.2016.147

14. De Larrea CF, Kyle RA, Durie BG, Ludwig H, Usmani S, Vesole DH, et al. Plasma cell leukemia: consensus statement on diagnostic requirements, response criteria and treatment recommendations by the International Myeloma Working Group. Leukemia (2013) 27(4):780-91. doi:10.1038/ leu.2012.336

15. Schilling G, Hansen T, Shimoni A, Zabelina T, Pérez-Simón JA, Gutierrez NC, et al. Impact of genetic abnormalities on survival after allogeneic hematopoietic stem cell transplantation in multiple myeloma. Leukemia (2008) 22(6): 1250-5. doi:10.1038/leu.2008.88

\section{AUTHOR CONTRIBUTIONS}

Conception and design: EM and ML. Drafting the article: EM and NEJ. Critical revision of the article: ML and NK. Final approval of manuscript and accountable for all aspects of the work: all authors.

16. Roos-Weil D, Moreau P, Avet-Loiseau H, Golmard J-L, Kuentz M, Vigouroux S, et al. Impact of genetic abnormalities after allogeneic stem cell transplantation in multiple myeloma: a report of the Societe Francaise de Greffe de Moelle et de Therapie Cellulaire. Haematologica (2011) 96(10): 1504-11. doi:10.3324/haematol.2011.042713

17. Nishihori T, Ochoa-Bayona JL, Kim J, Pidala J, Shain K, Baz R, et al. Allogeneic hematopoietic cell transplantation for consolidation of VGPR or CR for newly diagnosed multiple myeloma. Bone Marrow Transplant (2013) 48(9):1179-84. doi:10.1038/bmt.2013.37

18. Kröger N, Badbaran A, Zabelina T, Ayuk F, Wolschke C, Alchalby H, et al. Impact of high-risk cytogenetics and achievement of molecular remission on long-term freedom from disease after autologous-allogeneic tandem transplantation in patients with multiple myeloma. Biol Blood Marrow Transplant (2013) 19(3):398-404. doi:10.1016/j.bbmt.2012.10.008

19. Knop S, Liebisch P, Hebart H, Holler E, Engelhardt M, Metzner B, et al. Autologous followed by allogeneic versus tandem-autologous stem cell transplant in newly diagnosed FISH-del13q myeloma. Am Soc Hematol (2014) 124:43.

20. Gahrton G, Svensson H, Cavo M, Apperley J, Bacigalupo A, Björkstrand B, et al. Progress in allogeneic bone marrow and peripheral blood stem cell transplantation for multiple myeloma: a comparison between transplants performed 1983-93 and 1994-98 at European Group for Blood and Marrow Transplantation centres. Br J Haematol (2001) 113(1):209-16. doi:10.1046/j.1365-2141.2001.02726.x

21. Kröger N, Shimoni A, Schilling G, Schwerdtfeger R, Bornhäuser $M$, Nagler A, et al. Unrelated stem cell transplantation after reduced intensity conditioning for patients with multiple myeloma relapsing after autologous transplantation. Br J Haematol (2010) 148(2):323-31. doi:10.1111/j.13652141.2009.07984.x

22. Kawamura K, Takamatsu H, Ikeda T, Komatsu T, Aotsuka N, Amano I, et al. Cord blood transplantation for multiple myeloma: a study from the multiple myeloma working group of the Japan society for hematopoietic cell transplantation. Biol Blood Marrow Transplant (2015) 21(7):1291-8. doi:10.1016/j.bbmt.2015.02.015

23. Paviglianiti A, Xavier E, Ruggeri A, Ceballos P, Deconinck E, Cornelissen JJ, et al. Outcomes of unrelated cord blood transplantation in patients with multiple myeloma: a survey on behalf of Eurocord, the cord blood committee of cellular therapy and immunobiology working party, and the chronic leukemia working party of the European Society for Blood and Marrow Transplantation. Haematologica (2016) 101(9):1120-7. doi:10.3324/haematol.2015.138917

24. Castagna L, Mussetti A, Devillier R, Dominietto A, Marcatti M, Milone G, et al. Haploidentical allogeneic hematopoietic cell transplantation for multiple myeloma using post-transplantation cyclophosphamide Graft-versus-host disease prophylaxis. Biol Blood Marrow Transplant (2017) 23(9):1549-54. doi:10.1016/j.bbmt.2017.05.006

25. McKiernan P, Vesole DH, Siegel DS, Rowley SD, Baker MF, Diaz B, et al. Haploidentical allogeneic transplantation as salvage in relapsed multiple myeloma. Blood (2014) 124(21):5918.

26. Ho VT, Soiffer RJ. The history and future of T-cell depletion as graftversus-host disease prophylaxis for allogeneic hematopoietic stem cell transplantation. Blood (2001) 98(12):3192-204. doi:10.1182/blood.V98.12. 3192

27. Ayuk F, Zander A, Kröger N. Antitumor effects of polyclonal antithymocyte globulins: focus on B-cell malignancies and multiple myeloma. Ann Hematol (2009) 88(5):401-4. doi:10.1007/s00277-009-0696-8

28. Ayuk F, Perez-Simon JA, Shimoni A, Sureda A, Zabelina T, Schwerdtfeger R, et al. Clinical impact of human Jurkat T-cell-line-derived antithymocyte globulin in multiple myeloma patients undergoing allogeneic stem cell transplantation. Haematologica (2008) 93(9):1343-50. doi:10.3324/ haematol.12665 
29. Soiffer RJ, LeRademacher J, Ho V, Kan F, Artz A, Champlin RE, et al. Impact of immune modulation with anti-T-cell antibodies on the outcome of reduced-intensity allogeneic hematopoietic stem cell transplantation for hematologic malignancies. Blood (2011) 117(25):6963-70. doi:10.1182/ blood-2011-01-332007

30. Smith E, Devlin SM, Kosuri S, Orlando E, Landau H, Lesokhin AM, et al. CD34-selected allogeneic hematopoietic stem cell transplantation for patients with relapsed, high-risk multiple myeloma. Biol Blood Marrow Transplant (2016) 22(2):258-67. doi:10.1016/j.bbmt.2015.08.025

31. Shah N, Martin-Antonio B, Yang H, Ku S, Lee DA, Cooper LJ, et al. Antigen presenting cell-mediated expansion of human umbilical cord blood yields log-scale expansion of natural killer cells with anti-myeloma activity. PLoS One (2013) 8(10):e76781. doi:10.1371/journal.pone.0076781

32. Shah N, Li L, McCarty J, Kaur I, Yvon E, Shaim H, et al. Phase I study of cord blood-derived natural killer cells combined with autologous stem cell transplantation in multiple myeloma. Br J Haematol (2017) 177(3):457-66. doi:10.1111/bjh.14570

33. Kröger N, Shaw B, Iacobelli S, Zabelina T, Peggs K, Shimoni A, et al. Comparison between antithymocyte globulin and alemtuzumab and the possible impact of KIR-ligand mismatch after dose-reduced conditioning and unrelated stem cell transplantation in patients with multiple myeloma. Br J Haematol (2005) 129(5):631-43. doi:10.1111/j.1365-2141.2005. 05513.x

34. Kroger N, Zabelina T, Berger J, Duske H, Klyuchnikov E, Binder T, et al. Donor KIR haplotype B improves progression-free and overall survival after allogeneic hematopoietic stem cell transplantation for multiple myeloma. Leukemia (2011) 25(10):1657-62. doi:10.1038/leu.2011.138

35. Bensinger WI, Buckner CD, Anasetti C, Clift R, Storb R, Barnett T, et al. Allogeneic marrow transplantation for multiple myeloma: an analysis of risk factors on outcome. Blood (1996) 88(7):2787-93.

36. Barlogie B, Kyle RA, Anderson KC, Greipp PR, Lazarus HM, Hurd DD, et al. Standard chemotherapy compared with high-dose chemoradiotherapy for multiple myeloma: final results of phase III US Intergroup Trial S9321. J Clin Oncol (2006) 24(6):929-36. doi:10.1200/JCO.2005.04.5807

37. Lokhorst HM, Segeren CM, Verdonck LF, van der Holt B, Raymakers R, van Oers $\mathrm{MH}$, et al. Partially T-cell-depleted allogeneic stem-cell transplantation for first-line treatment of multiple myeloma: a prospective evaluation of patients treated in the phase III study HOVON 24 MM. J Clin Oncol (2003) 21(9):1728-33. doi:10.1200/JCO.2003.04.033

38. Bensinger W, Rotta M, Storer B, Chauncey T, Holmberg L, Becker P, et al. Allo-SCT for multiple myeloma: a review of outcomes at a single transplant center. Bone Marrow Transplant (2012) 47(10):1312-7. doi:10.1038/ bmt.2012.1

39. Auner HW, Szydlo R, van Biezen A, Iacobelli S, Gahrton G, Milpied N, et al. Reduced intensity-conditioned allogeneic stem cell transplantation for multiple myeloma relapsing or progressing after autologous transplantation: a study by the European Group for Blood and Marrow Transplantation. Bone Marrow Transplant (2013) 48(11):1395-400. doi:10.1038/bmt.2013.73

40. Gahrton G, Tura S, Ljungman P, Belanger C, Brandt L, Cavo M, et al. Allogeneic bone marrow transplantation in multiple myeloma. $N$ Engl J Med (1991) 325(18):1267-73. doi:10.1056/NEJM199110313251802

41. Alyea E, Weller E, Schlossman R, Canning C, Mauch P, Ng A, et al. Outcome after autologous and allogeneic stem cell transplantation for patients with multiple myeloma: impact of graft-versus-myeloma effect. Bone Marrow Transplant (2003) 32(12):1145-51. doi:10.1038/sj.bmt.1704289

42. Kumar S, Zhang M-J, Li P, Dispenzieri A, Milone GA, Lonial S, et al. Trends in allogeneic stem cell transplantation for multiple myeloma: a Center for International Blood and Marrow Transplant Research (CIBMTR) analysis. Blood (2011) 118:1979-88. doi:10.1182/blood-2011-02-337329

43. Bacigalupo A, Ballen K, Rizzo D, Giralt S, Lazarus H, Ho V, et al. Defining the intensity of conditioning regimens: working definitions. Biol Blood Marrow Transplant (2009) 15(12):1628-33. doi:10.1016/j.bbmt.2009.07.004

44. Armeson K, Hill E, Costa L. Tandem autologous vs autologous plus reduced intensity allogeneic transplantation in the upfront management of multiple myeloma: meta-analysis of trials with biological assignment. Bone Marrow Transplant (2013) 48(4):562-7. doi:10.1038/bmt.2012.173

45. Rosiñol L, Pérez-Simón JA, Sureda A, de la Rubia J, de Arriba F, Lahuerta JJ, et al. A prospective PETHEMA study of tandem autologous transplantation versus autograft followed by reduced-intensity conditioning allogeneic transplantation in newly diagnosed multiple myeloma. Blood (2008) 112(9):3591-3. doi:10.1182/ blood-2008-02-141598

46. Garban F, Attal M, Michallet M, Hulin C, Bourhis JH, Yakoub-Agha I, et al. Prospective comparison of autologous stem cell transplantation followed by dose-reduced allograft (IFM99-03 trial) with tandem autologous stem cell transplantation (IFM99-04 trial) in high-risk de novo multiple myeloma. Blood (2006) 107(9):3474-80. doi:10.1182/blood-2005-09-3869

47. Bruno B, Rotta M, Patriarca F, Mordini N, Allione B, CarnevaleSchianca F, et al. A comparison of allografting with autografting for newly diagnosed myeloma. N Engl J Med (2007) 356(11):1110-20. doi:10.1056/ NEJMoa065464

48. Sun K, Wilkins DE, Anver MR, Sayers TJ, Panoskaltsis-Mortari A, Blazar BR, et al. Differential effects of proteasome inhibition by bortezomib on murine acute graft-versus-host disease (GVHD): delayed administration of bortezomib results in increased GVHD-dependent gastrointestinal toxicity. Blood (2005) 106(9):3293-9. doi:10.1182/blood-2004-11-4526

49. Vodanovic-Jankovic S, Hari P, Jacobs P, Komorowski R, Drobyski WR. NF- $\kappa$ B as a target for the prevention of graft-versus-host disease: comparative efficacy of bortezomib and PS-1145. Blood (2006) 107(2):827-34. doi:10.1182/ blood-2005-05-1820

50. O'shaughnessy M, Vogtenhuber C, Sun K, Sitcheran R, Baldwin AS, Murphy WJ, et al. Ex vivo inhibition of NF- $\mathrm{BB}$ signaling in alloreactive T-cells prevents graft-versus-host disease. Am J Transplant (2009) 9(3):452-62. doi:10.1111/j.1600-6143.2008.02533.x

51. Blanco B, Pérez-Simón JA, Sánchez-Abarca LI, Carvajal-Vergara X, Mateos J, Vidriales B, et al. Bortezomib induces selective depletion of alloreactive T lymphocytes and decreases the production of Th1 cytokines. Blood (2006) 107(9):3575-83. doi:10.1182/blood-2005-05-2118

52. Nencioni A, Schwarzenberg K, Brauer KM, Schmidt SM, Ballestrero A, Grünebach F, et al. Proteasome inhibitor bortezomib modulates TLR4induced dendritic cell activation. Blood (2006) 108(2):551-8. doi:10.1182/ blood-2005-08-3494

53. Koreth J, Stevenson KE, Kim HT, McDonough SM, Bindra B, Armand P, et al. Bortezomib-based graft-versus-host disease prophylaxis in HLA-mismatched unrelated donor transplantation. JClin Oncol (2012) 30(26):3202-8. doi:10.1200/JCO.2012.42.0984

54. Koreth J, Stevenson KE, Kim HT, Garcia M, Ho VT, Armand P, et al. Bortezomib, tacrolimus, and methotrexate for prophylaxis of graft-versus-host disease after reduced-intensity conditioning allogeneic stem cell transplantation from HLA-mismatched unrelated donors. Blood (2009) 114(18):3956-9. doi:10.1182/blood-2009-07-231092

55. McCarthy PL, Owzar K, Hofmeister CC, Hurd DD, Hassoun H, Richardson PG, et al. Lenalidomide after stem-cell transplantation for multiple myeloma. N Engl J Med (2012) 366(19):1770-81. doi:10.1056/ NEJMoa1114083

56. Goldschmidt H, Lokhorst HM, Mai EK, van der Holt B, Blau IW, Zweegman $\mathrm{S}$, et al. Bortezomib before and after high-dose therapy in myeloma: long-term results from the phase III HOVON-65/GMMG-HD4 trial. Leukemia (2017). doi:10.1038/leu.2017.211

57. Palumbo A, Cavallo F, Gay F, Di Raimondo F, Ben Yehuda D, Petrucci MT, et al. Autologous transplantation and maintenance therapy in multiple myeloma. N Engl J Med (2014) 371(10):895-905. doi:10.1056/NEJMoa 1402888

58. Wolschke C, Stübig T, Hegenbart U, Schönland S, Heinzelmann M, Hildebrandt Y, et al. Postallograft lenalidomide induces strong NK cellmediated antimyeloma activity and risk for T cell-mediated GvHD: results from a phase I/II dose-finding study. Exp Hematol (2013) 41(2):134-42.e3. doi:10.1016/j.exphem.2012.10.004

59. Kneppers E, van der Holt B, Kersten MJ, Zweegman S, Meijer E, Huls G, et al. Lenalidomide maintenance after nonmyeloablative allogeneic stem cell transplantation in multiple myeloma is not feasible: results of the HOVON 76 Trial. Blood (2011) 118(9):2413-9. doi:10.1182/blood-2011-04348292

60. Bruno B, Patriarca F, Sorasio R, Mattei D, Montefusco V, Peccatori J, et al. Bortezomib with or without dexamethasone in relapsed multiple myeloma following allogeneic hematopoietic cell transplantation. Haematologica (2006) 91(6):837-9.

61. Tricot G, Vesole DH, Jagannath S, Hilton J, Munshi N, Barlogie B. Graftversus-myeloma effect: proof of principle. Blood (1996) 87(3):1196-8. 
62. Alyea E, Weller E, Schlossman R, Canning C, Webb I, Doss D, et al. T-celldepleted allogeneic bone marrow transplantation followed by donor lymphocyte infusion in patients with multiple myeloma: induction of graft-versus-myeloma effect. Blood (2001) 98(4):934-9. doi:10.1182/blood.V98.4.934

63. Badros A, Barlogie B, Morris C, Desikan R, Martin SR, Munshi N, et al. High response rate in refractory and poor-risk multiple myeloma after allotransplantation using a nonmyeloablative conditioning regimen and donor lymphocyte infusions. Blood (2001) 97(9):2574-9. doi:10.1182/blood. V97.9.2574

64. El-Cheikh J, Crocchiolo R, Furst S, Ladaique P, Castagna L, Faucher C, et al. Lenalidomide plus donor-lymphocytes infusion after allogeneic stem-cell transplantation with reduced-intensity conditioning in patients with highrisk multiple myeloma. Exp Hematol (2012) 40(7):521-7. doi:10.1016/j. exphem.2012.02.009

65. Kröger N, Badbaran A, Lioznov M, Schwarz S, Zeschke S, Hildebrand Y, et al. Post-transplant immunotherapy with donor-lymphocyte infusion and novel agents to upgrade partial into complete and molecular remission in allografted patients with multiple myeloma. Exp Hematol (2009) 37(7):791-8. doi:10.1016/j.exphem.2009.03.008

66. Peggs KS, Mackinnon S, Williams CD, D’Sa S, Thuraisundaram D, Kyriakou C, et al. Reduced-intensity transplantation with in vivo T-cell depletion and adjuvant dose-escalating donor lymphocyte infusions for chemotherapysensitive myeloma: limited efficacy of graft-versus-tumor activity. Biol Blood Marrow Transplant (2003) 9(4):257-65. doi:10.1053/bbmt.2003. 50009

67. Peggs KS, Thomson K, Hart DP, Geary J, Morris EC, Yong K, et al. Doseescalated donor lymphocyte infusions following reduced intensity transplantation: toxicity, chimerism, and disease responses. Blood (2004) 103(4): 1548-56. doi:10.1182/blood-2003-05-1513

68. Dey BR, McAfee S, Colby C, Sackstein R, Saidman S, Tarbell N, et al. Impact of prophylactic donor leukocyte infusions on mixed chimerism, graft-versus-host disease, and antitumor response in patients with advanced hematologic malignancies treated with nonmyeloablative conditioning and allogeneic bone marrow transplantation. Biol Blood Marrow Transplant (2003) 9(5):320-9. doi:10.1016/S1083-8791(03)00077-6

69. Orsini E, Alyea EP, Chillemi A, Schlossman R, McLaughlin S, Canning C, et al. Conversion to full donor chimerism following donor lymphocyte infusion is associated with disease response in patients with multiple myeloma. Biol Blood Marrow Transplant (2000) 6(4):375-86. doi:10.1016/S1083-8791 (00)70014-0

70. Bellucci R, Alyea EP, Weller E, Chillemi A, Hochberg E, Wu CJ, et al. Immunologic effects of prophylactic donor lymphocyte infusion after allogeneic marrow transplantation for multiple myeloma. Blood (2002) 99(12): 4610-7. doi:10.1182/blood.V99.12.4610

71. Lokhorst HM, Schattenberg A, Cornelissen JJ, Thomas LL, Verdonck LF. Donor leukocyte infusions are effective in relapsed multiple myeloma after allogeneic bone marrow transplantation. Blood (1997) 90(10):4206-11.

72. Salama M, Nevill T, Marcellus D, Parker P, Johnson M, Kirk A, et al. Donor leukocyte infusions for multiple myeloma. Bone Marrow Transplant (2000) 26(11):1179-84. doi:10.1038/sj.bmt.1702685

73. Lokhorst HM, Wu K, Verdonck LF, Laterveer LL, van de Donk NW, van Oers MH, et al. The occurrence of graft-versus-host disease is the major predictive factor for response to donor lymphocyte infusions in multiple myeloma. Blood (2004) 103(11):4362-4. doi:10.1182/blood-2003-11-3862

74. Montefusco V, Spina F, Patriarca F, Offidani M, Bruno B, Montanari M, et al. Bortezomib plus dexamethasone followed by escalating donor lymphocyte infusions for patients with multiple myeloma relapsing or progressing after allogeneic stem cell transplantation. Biol Blood Marrow Transplant (2013) 19(3):424-8. doi:10.1016/j.bbmt.2012.10.032

75. Rasche L, Röllig C, Stuhler G, Danhof S, Mielke S, Grigoleit GU, et al. Allogeneic hematopoietic cell transplantation in multiple myeloma: focus on longitudinal assessment of donor chimerism, extramedullary disease and high risk cytogenetic features. Biol Blood Marrow Transplant (2016) 22(11):1988-96. doi:10.1016/j.bbmt.2016.08.024

76. de Carvalho F, Alves VL, Braga WM, Xavier CV Jr, Colleoni GW. MAGE-C1/ CT7 and MAGE-C2/CT10 are frequently expressed in multiple myeloma and can be explored in combined immunotherapy for this malignancy. Cancer Immunol Immunother (2013) 62(1):191-5. doi:10.1007/s00262-012-1376-4

77. Tyler EM, Jungbluth AA, O’Reilly RJ, Koehne G. WT1-specific T-cell responses in high-risk multiple myeloma patients undergoing allogeneic $\mathrm{T}$ cell-depleted hematopoietic stem cell transplantation and donor lymphocyte infusions. Blood (2013) 121(2):308-17. doi:10.1182/blood-2012-06-435040.

78. Maus MV, Grupp SA, Porter DL, June CH. Antibody-modified T cells: CARs take the front seat for hematologic malignancies. Blood (2014) 123(17): 2625-35. doi:10.1182/blood-2013-11-492231

79. Mackall CL, Merchant MS, Fry TJ. Immune-based therapies for childhood cancer. Nat Rev Clin Oncol (2014) 11(12):693-703. doi:10.1038/ nrclinonc.2014.177

80. Porter DL, Levine BL, Kalos M, Bagg A, June $\mathrm{CH}$. Chimeric antigen receptor-modified T cells in chronic lymphoid leukemia. N Engl J Med (2011) 365(8):725-33. doi:10.1056/NEJMoa1103849

81. Grupp SA, Kalos M, Barrett D, Aplenc R, Porter DL, Rheingold SR, et al. Chimeric antigen receptor-modified $\mathrm{T}$ cells for acute lymphoid leukemia. N Engl J Med (2013) 368(16):1509-18. doi:10.1056/NEJMoa1215134

82. Kochenderfer JN, Dudley ME, Kassim SH, Somerville RP, Carpenter RO, Stetler-Stevenson $\mathrm{M}$, et al. Chemotherapy-refractory diffuse large B-cell lymphoma and indolent B-cell malignancies can be effectively treated with autologous T cells expressing an anti-CD19 chimeric antigen receptor. J Clin Oncol (2014) 33(6):540-9. doi:10.1200/JCO.2014.56.2025

83. Garfall AL, Maus MV, Hwang WT, Lacey SF, Mahnke YD, Melenhorst JJ, et al. Chimeric antigen receptor T cells against CD19 for multiple myeloma. N Engl J Med (2015) 373(11):1040-7. doi:10.1056/NEJMoa1504542

84. Fan F, Zhao W, Liu J, He A, Chen Y, Cao X, et al. Durable remissions with BCMA-specific chimeric antigen receptor (CAR)-modified $\mathrm{T}$ cells in patients with refractory/relapsed multiple myeloma. Am Soc Clin Oncol (2017) 35(18). doi:10.1200/JCO.2017.35.18_suppl.LBA3001

85. Garfall AL, Fraietta JA, Maus MV. Immunotherapy with chimeric antigen receptors for multiple myeloma. Discov Med (2014) 17(91):37-46.

86. Garfall AL, Stadtmauer EA. Cellular and vaccine immunotherapy for multiple myeloma. Hematology Am Soc Hematol Educ Program (2016) 2016(1):521-7. doi:10.1182/asheducation-2016.1.521

87. Garfall AL, Stadtmauer EA, June $\mathrm{CH}$. Chimeric antigen receptor T cells in myeloma. N Engl J Med (2016) 374(2):194. doi:10.1056/NEJMc1512760

Conflict of Interest Statement: The authors declare that the research was conducted in the absence of any commercial or financial relationships that could be construed as a potential conflict of interest.

Copyright (C) 2017 Malek, El-Jurdi, Kröger and de Lima. This is an open-access article distributed under the terms of the Creative Commons Attribution License (CC BY). The use, distribution or reproduction in other forums is permitted, provided the original author(s) or licensor are credited and that the original publication in this journal is cited, in accordance with accepted academic practice. No use, distribution or reproduction is permitted which does not comply with these terms. 